Original article

\title{
Community livelihood activities as key determinants for community based conservation of wetlands in Uganda
}

\author{
Alex Barakagira*, Anton H. de Wit \\ Faculty of Science, Nelson Mandela Metropolitan University, P.O. Box 77000, Port Elizabeth, South Africa \\ E-mail address (*corresponding author): barakalexham2@gmail.com
}

\begin{abstract}
Community-based Conservation (CBC) has been regarded as one of the most appropriate approaches to the sustainable utilization and conservation of natural resources. Wetlands are believed to provide attributes, functions, and services that positively affect the daily livelihoods of members of the local community. Bearing in mind the incentives wetlands provide, if community members are not involved in the activities aimed at the management and conservation of wetlands then they result in being degraded. This study was initiated to explore how community livelihood activities influence CBC of wetlands in Uganda. A cross-sectional research design was used to collect qualitative and quantitative data. A questionnaire survey was conducted among four hundred households to collect information concerning community livelihood activities taking place in wetlands. Additionally, more information was obtained from National Environment Management Authority, and Wetlands Management Department staff using another non-structured questionnaire. Key informant interviews and direct observations were also used to collect data. Overall, the gathering of materials for building and crafts, fuel wood collection, clay and sand mining and practicing agriculture in wetlands are some of the reasons that have caused wetland degradation. Low levels of awareness, unclear ownership of wetlands and inadequate funding has not enabled Agencies responsible for implementing the Policies and Laws aimed for protecting and conserving wetlands from being degraded. Therefore, these above mentioned problems must be addressed in order for wetland resources to be sustainably utilized and conserved by members of the local community.
\end{abstract}

KEY WORDS: local community, conservation, wetlands, Uganda

ARTICLE HISTORY: received 17 January 2017; received in revised form 4 March 2017; accepted 10 March 2017

\section{Introduction}

Wetlands are among the most productive life supporting systems in the world and are of immense socio-economic and ecological importance to mankind. They are critical for the maintenance of biodiversity and perform a huge role in the biosphere. Wetlands in Uganda are areas used for cattle grazing, water filtration for domestic use; and in addition they retain nutrients and toxins. They provide water for irrigation, hydro-power generation, fisheries, recreation, transport and human and industrial disposal as reported by MiniSTRY OF NATURAL RESOURCES (1995) and MiNISTRY OF WATER AND ENVIRONMENT (2005).

In Uganda however, UGANDA BUREAU OF STANDARDS (2002) reported that more than seven percent of the original wetland areas have been converted to other uses by the growing population, at an estimated rate of $3.3 \%$, which has resulted in the loss of biodiversity especially for species that inhabit wetlands.

Globally, BERKES (2007) states that conservation originally relied on national parks controlled by central governments, a model adopted by much of the world as the main way, if not the only way to carry out conservation. Until the 1970s, most conservation laws and designations of protected areas such as national parks and wildlife sanctuaries in developing countries followed the 'preservation - oriented' approach. This advocated centralized regulatory control and excluded local people and their subsistence forest-based activities that often alienated them from biodiversity 
protection activities as reported by SHAMA (1990), Ghimire \& Pimbert (1997), and MurPhreE \& Hulme (2001). Conservation authorities perceived natural resource conservation as mainly requiring the establishment of exclusive protected areas. Human communities therein were solely viewed as threats to conservation efforts and were often halted or restricted from utilizing resources found in these protected areas for their livelihood purposes as reported by TIMMER (2004). Such one-sided conservation efforts as stated by DAFFA ET AL. (2002), were mostly driven by political elites, and frequently included the forced removal and/or resettlement of affected communities from designated conservation areas. Thus the science and approach of conservation had for a long time been almost exclusively been resource and expert - based, centralized, and typically 'top-down' without much, if any, concern for the needs of the affected human communities. Since local communities were sometimes adversely affected, conventional conservation was therefore, increasingly perceived as being illegitimate in the face of the needs of human development as reported by FORGIE ET AL. (2001), and Timmer (2004). Wildlife conservation as perceived by MUNTHALI (1993) was often viewed as alien, hypocritical, and as favouring foreigners by members of the local community. Hence, such conservation, as clearly stated by THATCHER (1984), HOUGH \& SHERPA (1989), resulted in less, if not none, of the support from local people, and this action was reflected in the increased poaching behavior, more encroachment on protected areas, agricultural expansion that altered wildlife habitat, and the unsustainable harvesting of resources which led to protected area-people conflicts that undermined the long term biodiversity conservation efforts.

In Uganda, early CBC was built and evolved from Protected Area Outreach, which primarily focused on savannah national parks (BARROW ET AL., 1997), but did not sufficiently address the protection of Ugandas' wetlands as stated by BARROW ET AL. (2000) and yet wetlands are important areas known for their high biodiversity and for many functions, values and attributes as reported by BOS ET AL. (2005). However, a decline in the existing conservation was observed between the mid-1970s to mid-1980s that swept away most conservation management programmes brought about by the then government that did not prioritize the conservation of natural resources. This culminated in the misuse of natural resources including wetlands in Uganda. MuPHREE (1993) reported that, the community-based wildlife management that spread through southern and central Africa made very little progress on matters concerning the conservation of wetlands which progressively became degraded as a result of various activities by local people being undertaken therein. This implies that a change in the local people's wetland resource utilization and conservation methods is imperative if not urgent. The objectives of this study were thus three fold, namely to:

i. Identify and characterize activities carried out by local communities in wetlands found in Central and Western regions of Uganda that are responsible for their progressive degradation;

ii. Determine the community activities which should be practiced that are aimed at sustainable wetland resource utilization and conservation;

iii. Assess the performance of existing Wetland Management Institutions through the implementation of Acts, Policies, and Statutes aimed at the protection and conservation of wetlands by members of the local community found in the Central and Western regions of Uganda.

\section{Study area}

The Central and Western regions of Uganda were considered in the study (Fig. 1). This is because as the majority of wetlands found in these regions are still undergoing degradation, or have already been degraded, in order to satisfy the growing population with more land mainly for agriculture (MINISTRY OF WATER AND ENVIRONMENT, 2009); WetLands MANAGEMENT DePARTMENT, 2013). However, not all the wetlands in the study area have been, or are undergoing degradation, and the reasons for which will be used as recommendations to the local communities in other parts of the Country, where degradation is evident, and will be aimed at conserving the remaining wetlands.

The study focused on permanent wetlands in the Central and Western regions in Uganda. This is because; temporary wetlands would be difficult to locate in dry seasons during the course of the study. The Central and Western regions in Uganda are divided into districts. Bearing in mind that wetlands in Uganda are diverse and spread throughout the Country as reported by NTAMBIRWEKI (1998) and BOS ET AL. (2005), selection of the districts to include in the study was probabilistic. A simple random sample of ten districts, five districts from each region, was taken to determine the districts to include in the study. The districts that were selected include Kampala, Mpigi, Mukono, Rakai, and Wakiso in the Central region (Fig. 2). From the Western region, the districts that were selected include Bushenyi, Kabale, Mbarara, 
Ntungamo, and Rukungiri (Fig. 3). After randomly selecting the districts where the study would be undertaken, a simple random sample of two permanent wetlands from each district was conducted to arrive at a total of twenty wetlands within which the study was conducted, as shown in Fig. 2 and Fig. 3.

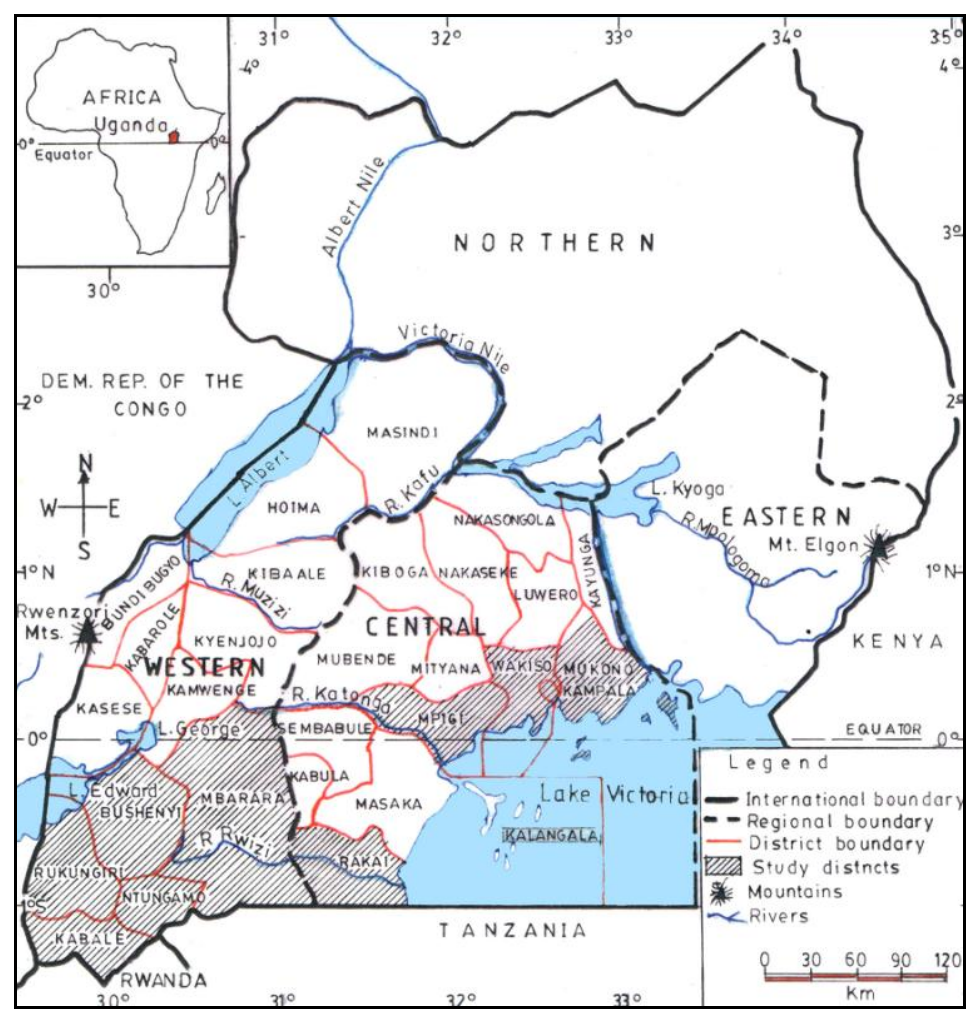

Fig. 1. Location of the districts of Uganda where the study was carried out, 2015

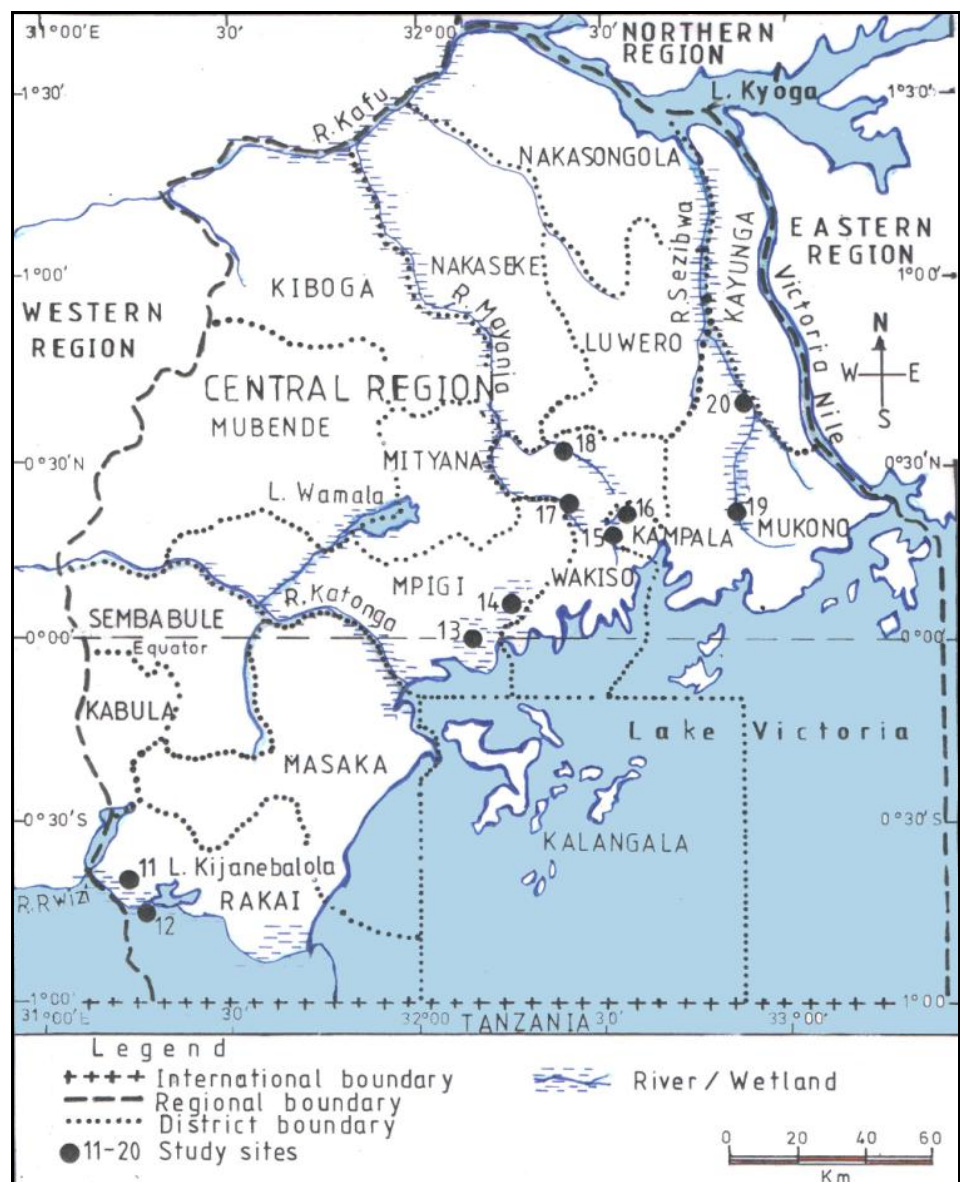

Fig. 2. Location of the study areas in the Central Region of Uganda, 2015 


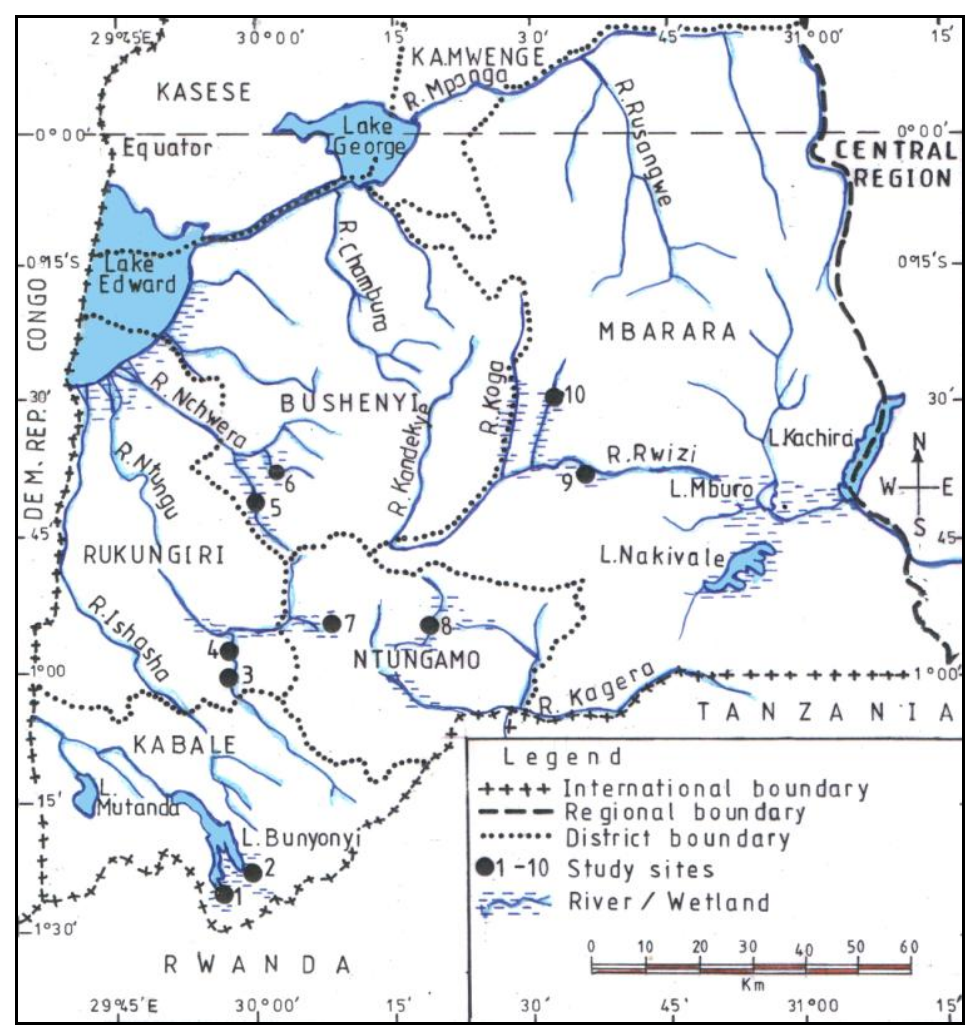

Fig. 3. Location of the study areas in the Western Region of Uganda, 2015

\section{Materials and methods}

The research project was centered on determining the livelihood activities that are carried out within the wetlands in order to determine whether these activities are compatible with the conservation of wetlands in Central and Western Uganda, and to determine the community activities which members of the local community should practice, within wetlands, that may lead to their sustainable utilization and conservation; and also to assess the performance of existing Wetlands Management Institutions towards implementing the Acts, Policies, and Statutes which are aimed at the protection and conservation of wetlands at the grass roots level in Uganda.

Both qualitative and quantitative data was obtained from the respondents in order to generate the information needed for community conservation of wetlands in Uganda. Qualitative data as reported by SARANTAKOS (2005) and LINDLOF \& TAYLOR (2011) helped to verify and enrich the quantitative data obtained from the study. A series of complementary methods were used to collect a vast amount of data with the advantage that the methods enhanced the capacity for interpreting the data captured as suggested by HOGGART ET AL. (2002).

Questionnaires were used to collect primary data from the respondents in the study area, and officials from Lead Agencies in the management of wetlands which included National Environment Management Authority and Wetlands Management Department, District Natural Resources Officers, and Officials working with the NGOs that operate activities related to wetland management and conservation.

The questionnaire was pre-tested in one district that was not part of the selected sample. Pretesting allowed the interviewers to gain familiarity with the questionnaire and provided an opportunity to apply and review the method. The focus was on assessing how respondents understood the questions and to identify any problems encountered in providing answers. Changes were proposed, reviewed and incorporated into the final questionnaire. The questionnaire focused on the respondents' understanding of activities carried out by the local communities that are responsible for the degradation of these wetlands and the activities that members of the local community would practice within wetlands that may culminate in their sustainable utilization and conservation.

A questionnaire survey was conducted among four hundred households which were randomly selected. The four hundred households were obtained by first, randomly selecting twenty permanent wetlands from the Central and Western regions. This was followed by a systematic random sample of twenty households from nearby, or around the selected wetland. The first household 
was randomly selected and the successive households were selected after every $5^{\text {th }}$ household. One adult person (18 years and above) from each household was then selected, approached, briefed and informed that the purpose of the research was purely academic and had no legal implications whatsoever, and that the respondents were also assured of confidentiality and anonymity. The questionnaire was then administered to the respondent which in most cases was semistructured, and in the common local language, since the majority of the respondents were illiterate (Table 1).

Another questionnaire was designed and administered to the Policy makers and implementers in National Environment Management Authority and Wetlands Management Department who occupy managerial positions concerned with wetland protection and conservation using a positional approach as suggested by BRANCH ET AL. (1984) and HYMAN ET AL. (2001). The aim was to gather information concerning the performance of the existing Acts, Policies, and Statutes concerned with wetland protection and conservation at the grass roots level.

Key informant interviews were held with District Natural Resources Officers in the study areas, managers of NGOs operating in the selected study areas, Sub-county chiefs, Local Council III chairpersons, Local Council I chairpersons and Village Environmental Councilors. The aim was to collect information regarding community livelihood activities which take place in wetlands in order to ascertain whether the activities were compatible with the sustainable utilization and conservation of wetlands. Also, to obtain information about the activities that would be practiced in wetlands that would lead to sustainable wetland resource utilization and conservation by members of the local community. Also to ascertain whether the Acts, Policies, and Statutes formulated to protect and conserve wetlands at the local level were being implemented.

In addition, direct field observations were made on activities undertaken in the sample wetlands to ascertain whether the utilization of wetland resources by the local people was sustainable. Direct field observations were also used to verify the reliability of the information the research participants had provided to the researcher regarding the study topic. The state of wetlands in relation to utilization of resources and their conservation were depicted with the help of digital photographs and their location was recorded as coordinates in a Global Positioning System for the purpose of further reference.

Questionnaire responses were edited, coded, and analyzed using SPSS version 16.0 for Windows. This informed descriptive statistics concerning community livelihood activities that are carried out within the wetlands, for the purpose of ascertaining whether the activities were compatible with the conservation measures of the wetlands. The analyzed data was then accompanied with notes to direct the readers' attention to important values for comparison. Percentage values were used to relate what is in the frequency distribution tables together with the likely cause of the outcome. Generalization of the data was made while reporting on the data based on the percentages obtained for particular items in the survey. Generalization as reported by SARANTAKOs (2005) ensures extrapolation of the research findings beyond the boundaries of the research sample to the whole population.

Qualitative data collected during interactive informant interviews was sorted and categorized into themes according to particular items of interest as reported by SARANTAKOS (2005). In cases where a research participant gave a narrative for a particular response, efforts were made to reproduce the actual words, or conversations that were given from the field, based on the popular themes of the study. In some cases, Chi square test was used to test for association of attributes.

\section{Results}

\subsection{Household characteristics}

The majority (53\%) of respondents were female and $29 \%$ of the respondents were of an average age of twenty five years. Most respondents (74\%) had never studied beyond Primary seven level of Education (elementary level), while 90\% of the respondents never studied beyond Secondary level of education. The main occupation of the respondents was farming. Their other source of income included petty trade in household items, crafts and brick making, casual labour and a few were civil servants. Slightly over two-thirds (68\%) of respondents had an average household size of four family members of whom, about $85 \%$ depended on immediate natural resources for a livelihood (Table 1). 
Table 1. Household characteristics of respondents, Author's questionnaire survey

\begin{tabular}{|c|c|c|}
\hline Characteristic & Frequency & Percent \\
\hline \multicolumn{3}{|l|}{ Gender } \\
\hline Male & 187 & 46.8 \\
\hline Female & 213 & 53.2 \\
\hline \multirow{2}{*}{\multicolumn{3}{|c|}{$10-19$}} \\
\hline & & \\
\hline $20-29$ & 114 & 28.5 \\
\hline $30-39$ & 99 & 24.8 \\
\hline $40-49$ & 62 & 15.5 \\
\hline $50-59$ & 40 & 10.0 \\
\hline 60 and above & 52 & 13.0 \\
\hline \multicolumn{3}{|l|}{ Level of education } \\
\hline None & 101 & 25.4 \\
\hline Lower Primary (P1 - P4) & 40 & 10.0 \\
\hline Upper Primary (P5 - P7) & 152 & 38.2 \\
\hline Secondary & 68 & 17.1 \\
\hline Post Secondary & 26 & 6.5 \\
\hline Graduate & 11 & 2.8 \\
\hline \multicolumn{3}{|l|}{ Occupation } \\
\hline Peasant & 269 & 67.2 \\
\hline Student & 17 & 4.3 \\
\hline Business Person & 44 & 11.0 \\
\hline Public Servant & 18 & 4.5 \\
\hline Other & 48 & 12.0 \\
\hline Missing System & 4 & 1.0 \\
\hline \multicolumn{3}{|l|}{ Household size } \\
\hline $1-3$ & 128 & 32.0 \\
\hline $4-6$ & 150 & 37.5 \\
\hline $7-9$ & 79 & 19.8 \\
\hline 10 and above & 40 & 10.0 \\
\hline Missing System & 3 & 0.7 \\
\hline
\end{tabular}

4.2. Activities carried out by the local communities responsible for degradation of wetlands

The majority of respondents (79\%) reported that various activities including gathering materials for building and crafts (76\%), in most cases left wetland ecosystems bare (Fig. 4 at S01025.039/ E029056.643/) and contributed the most to wetland degradation especially in the western region. Other activities that significantly contributed to wetland degradation included fuel wood collection (45\%), and clay mining for brick making as reported by $8 \%$ of respondents (Table 2). Urban expansion as a result of increased population numbers, as shown by a high average number (at least four members in each of $68 \%$ households) of people, combined with low levels of formal education encouraged members of the local community to reclaim wetlands for industrial and house construction (Fig. 5 and Fig. 6 respectively).

Table 2. Activities undertaken in the wetlands before reclamation, Author's questionnaire survey; Percent of cases* is more than one hundred percent because of multiple responses

\begin{tabular}{|l|c|c|}
\hline \multicolumn{1}{|c|}{ Activities } & Responses (N=316) & Percent of cases* \\
\hline Gathering materials for building and crafts & 240 & 76.0 \\
\hline Fishing & 155 & 49.1 \\
\hline Hunting & 84 & 26.6 \\
\hline Clay mining & 25 & 7.9 \\
\hline Fuel wood collection & 143 & 45.3 \\
\hline
\end{tabular}




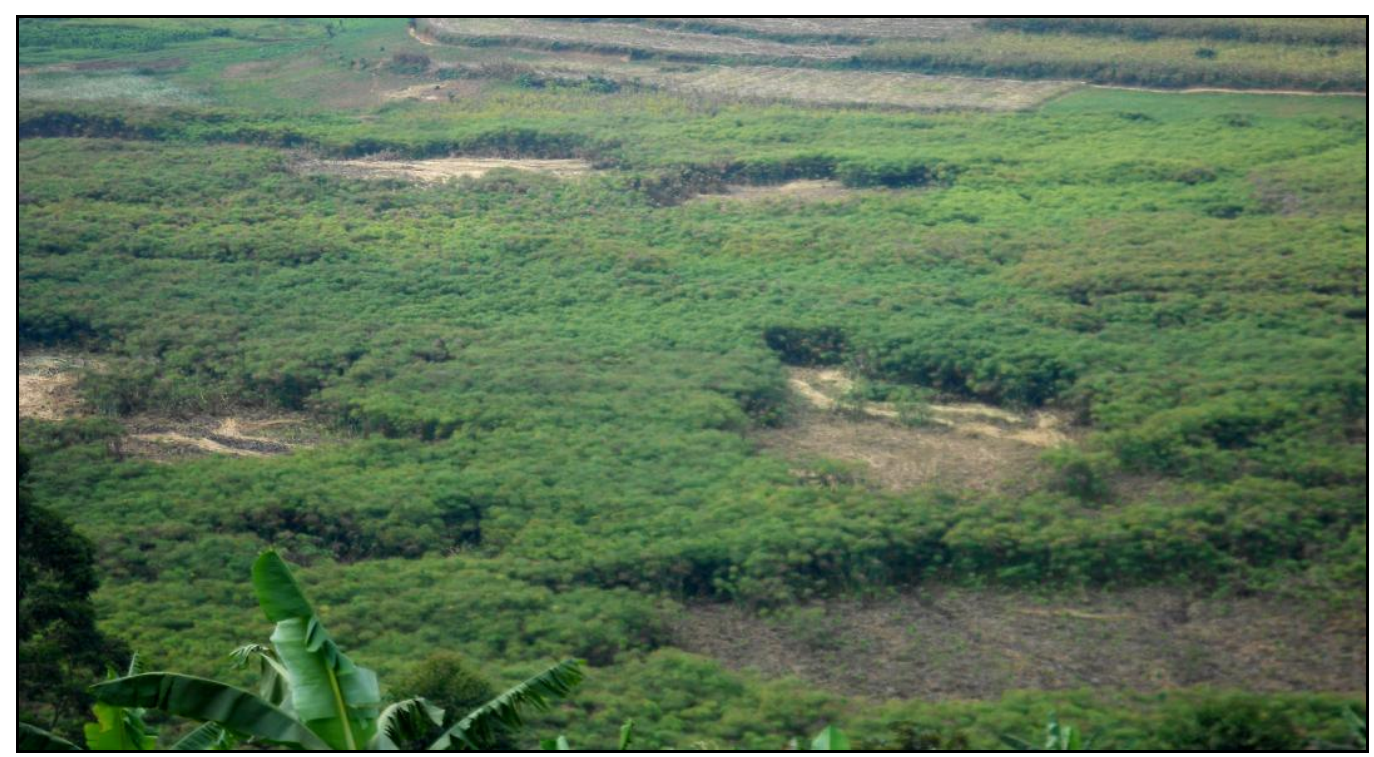

Fig. 4. Big pockets left due to over harvesting of wetlands resources in the un-reclaimed wetland by members of the local community in the Western Region, by Alex Barakagira, 2013

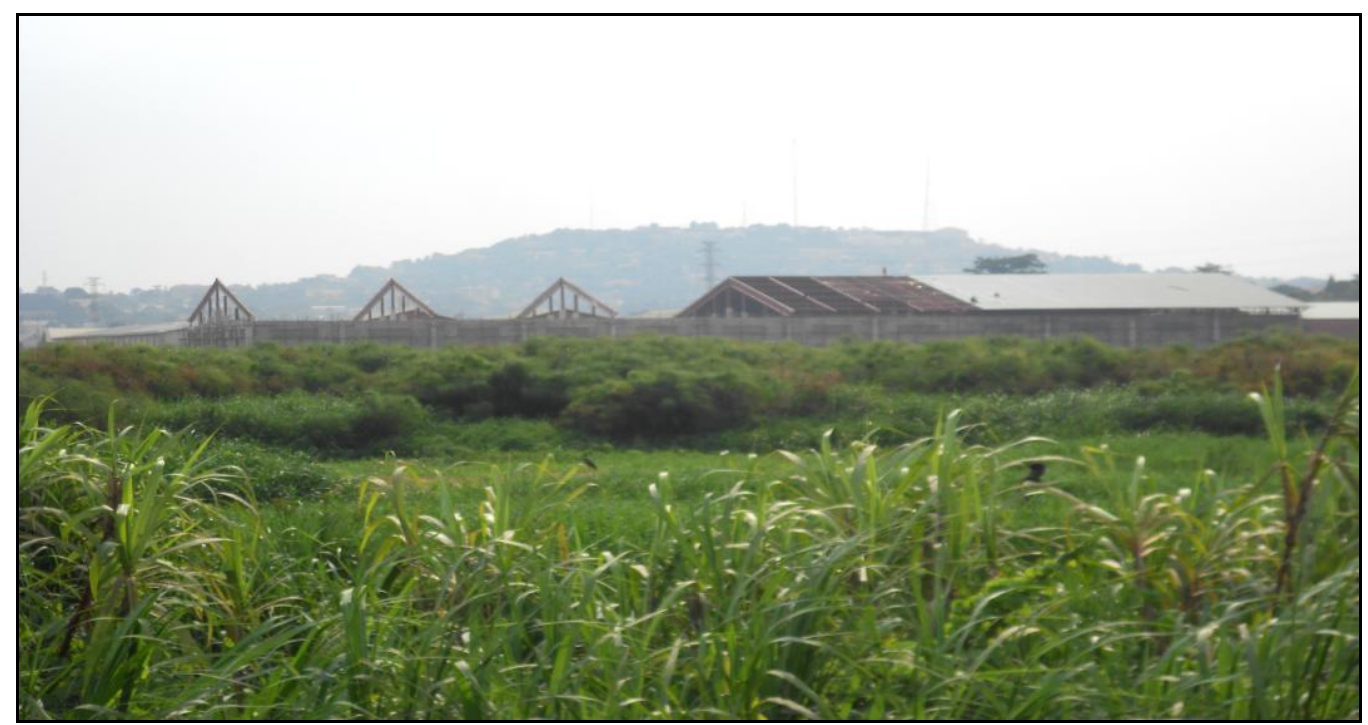

Fig. 5. An industry under construction in a reclaimed wetland near the Capital City - Kampala, in the Central Region, by Alex Barakagira, 2013

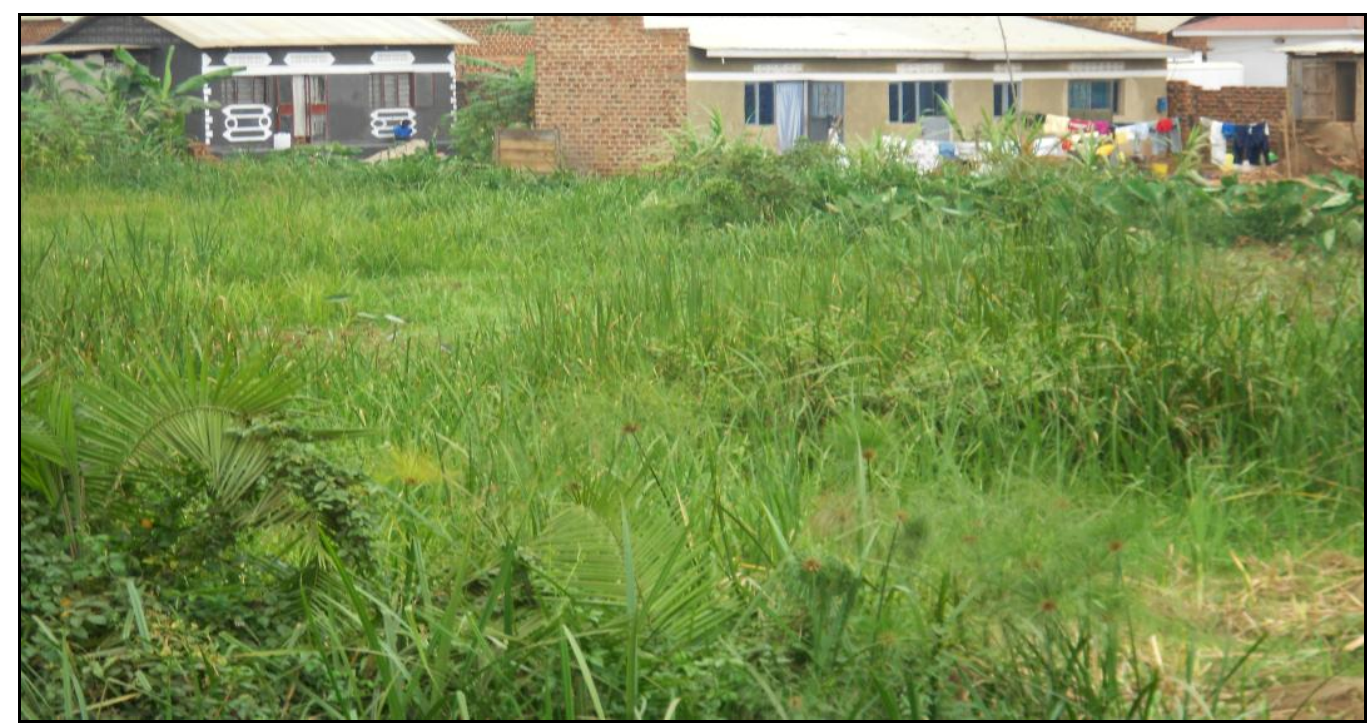

Fig. 6. Houses which have been constructed in a wetland near Kampala, the Capital City of Uganda, in the Central Region, by Alex Barakagira, 2013 
Apart from the above activities that directly contributed to the degradation of wetlands in the study area, the following circumstances led to wetland degradation in Uganda:

1) Low levels of formal education by members of the local community. As already noted, about $90 \%$ of the respondents never studied beyond the level of Secondary school education. Such low levels of formal education did not allow members of the local community to seek formal employment and so mainly became involved in activities that degraded natural resources, including wetlands, to satisfy their immediate needs. The majority of members of the local community (79\%) reported that the income obtained from the sale of wetland products was used to buy household items, while $69 \%$ of community members used this income to pay for school fees. Other members $(41 \%)$ paid for health services while others $(13 \%)$ injected money into income generating activities. Such benefits realized by members of the local community encouraged them to always seek economic satisfaction from wetlands and ended up degrading them. It is no wonder that, over half (56\%) of the respondents reported that they wished to access and harvest wetland resources on a daily basis. The study revealed that there was an association between the levels of education of respondents and the benefits obtained from wetland resources $\left(\chi^{2}=3.785, \mathrm{df}=5, \mathrm{P}=0.581\right)$. Also, there was an association between the levels of education of the community members and their utilization of resources from wetlands $\left(\chi^{2}=42.166, d f=15\right.$, $\mathrm{P}=0.000)$ that contributed to their degradation. Low levels of education also would not allow members of the local community to understand the indirect values wetlands provide. This was evidenced by the fact that three quarters (75\%) of the respondents reported that they benefited from the existing wetlands because these are areas which provide more land for agriculture (49\%), building spaces (13\%), while other members of the community $(6 \%)$ reported that they mine sand and clay used for molding building bricks for sale. None of the members mentioned any indirect values which wetlands provide. In addition to the inability of members of the local community to discern any indirect values wetlands provide, they attached little value to the wetlands where almost two-thirds (66\%) of the respondents reported that they were willing to incur a cost of an average UGX 500 (approximately USD 0.185) per month in a bid to protect wetlands from further degradation, while the rest of the members of the community were not willing to incur any cost in a bid to conserve wetlands.

2) Unclear ownership of wetlands in the study area also contributed to their degradation. Four types of land tenure systems, that is: Customary; Freehold; Mailo; and Leasehold exist in Uganda. However, a proportion of respondents (39\%) reported that wetlands are owned by people who own land adjacent to the wetlands. While other respondents $(12 \%)$ reported that local organized groups own wetlands. Only $33 \%$ of respondents stated that wetlands are owned by the Government. The four types of land tenure systems are concurrently applied in all parts of Uganda, of which each type has unique objectives in relation to ownership, management and transfer. This leaves members of the local community in confusion about which appropriate land tenure is most suitable for protection and conservation of wetlands, leading to their degradation. This was confirmed by the Chi-square test between level of education of respondents and ownership of wetlands. It was realized that there was a relationship between level of education of the respondents and the knowledge concerning ownership of wetlands $\left(\chi^{2}=17.474, \mathrm{df}=15, \mathrm{P}=0.291\right)$.

3) High population growth in the Country also propagated wetland degradation. In the study area, $68 \%$ of the respondents reported that the average number of people living in each household is four. The higher household numbers of people, coupled with reported infertile upland soils incapable of supporting agriculture practiced by most respondents $(67 \%)$ created a landless class of members of the local community, this situation has forced them to reclaim wetlands found in their surroundings, as in the quote below.

'When we settled in this area about 60 years ago, we had enough land for agriculture. The increase in number of people in individual households led to a shortage of land for agriculture. This condition forced us to reclaim the only wetland in this area to expand on our agricultural land'. The situation could even be worse if some of our children did not migrate to the city to seek for casual jobs' (One key

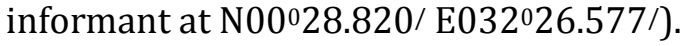

4) In relation to the above, the lack of alternative sources of income by members of the local community has contributed to the degradation of wetlands. As reported, $68 \%$ of the respondents were peasants and, therefore, they entirely depend on agriculture for a livelihood. Yet as observed, $90 \%$ of the respondents have not studied beyond secondary level of education. This means that a small 
proportion of the population in the study area is able to support their family members through alternative income other than agriculture. Hence, members of the community were forced to turn to wetlands which are regarded as 'free land' available for agricultural activities that have ended up degrading the wetlands.

5) Also, Lead Agencies responsible for protecting and conserving wetlands have not been sufficiently empowered to successfully conduct their work. It was reported that some posts at the local level of governance like Secretary for Production and Environment (Local Council 1) and Sub - county Committees are lacking, yet such posts, if filled, would assist Lead Agencies like National Environment Management Authority and Wetlands Management Department to implement policies aimed at protecting and conserving wetlands at the local level. Furthermore, it was realized that the Local Council 1 Committees are illegitimately occupying their offices hence are unable to effectively conduct their duties such as protecting natural resources, including wetlands. The last time Local Council 1 elections were held in Uganda was the year 2001 for a five year term in office. Since then, no Local Council 1 elections have been held to that effect. In addition, there has reportedly been inadequate funding to the Lead Agencies in order to implement what has been decided for wetland conservation. Thus, it is not surprising that, in each district of study, apart from the Kampala district, the Capital City, and Wakiso district, which neighbours the Capital City, only one Natural Resources Officer is available to overlook the protection and conservation of natural resources including wetlands. This situation has exacerbated the degradation of wetlands since it is known that wetlands in Uganda are diverse and hence only one civil servant may not be competent enough to perform the duties related to the protection of these wetlands from being degraded.

\subsection{Community activities that need to be practiced which aim for sustainable wetland resource utilization and conservation}

A host of resources (Table 2) were obtained from wetlands by members of the local community. These include materials for building and crafts (76\%), food (75\%) which include fish and game meat. A lot of other direct benefits are obtained by members of the local community from wetland resources that have improved on their livelihoods as already mentioned, and have encouraged them to continuously utilize the resources that in most cases led to wetland degradation. However, during the research study, it was realized that if the following were practiced by members of the local community, the sustainable utilization and conservation of wetlands would be realized.

1) Over half $(56 \%)$ of the members of local communities that reportedly benefited from wetlands stated that they would wish to access wetland resources daily, and yet, the majority (66\%) of the respondents reported that they were not ready to incur any cost in a bid to conserve wetlands. This was perceived as one of the activities that contributed to wetland degradation in the study areas. Hence, regulated access to wetland resources by community leaders was fronted by the respondents (55\%) as one of the ways that would promote sustainable utilization and conservation of wetland resources.

2) Wetland edge farming and aquaculture by members of the local community was also proposed by some District Natural Resources Officers as another option that would save wetlands from further degradation and hence help their conservation. The Officers argued that since some upland soils are no longer productive, encouraging members of the local community to practice farming at the edges of wetlands would reduce pressure on the entire wetland system and would act as an incentive to appreciate the existence of wetlands within the area. For aquaculture, the Officers pointed out that such a practice is better than complete reclamation of wetlands which would contribute to their degradation.

3 ) It was noticed during the research study that slightly over half (56\%) of the respondents were not aware of the programs aimed at the conservation of wetlands (Table 3), while other respondents $(44 \%)$ were aware of the programs through knowledge obtained from community meetings (51\%), local radio stations (28\%), local television stations (14\%), places of worship (3\%), news-papers (2\%), and through hearsay (12\%). Therefore, increased community sensitization about sustainable wetland resource utilization and conservation should be encouraged, especially through local community meetings.

4) Environment Protection Police Officials need to be increased and evenly distributed to most parts of the Country as reported by $61 \%$ of the Officials from the Lead Agencies including National Environment Management Authority, the Wetlands Management Department and also from Natural Resources Officers. This should be coupled with increased vigilance in the monitoring of activities 
undertaken within the wetlands, especially by involving local community leaders, who need to be empowered to do their work by electing them into the offices they occupy.

5) There should be a creation of wetland boundaries (planting trees along the edges of the wetlands by the Lead Agencies), since it was observed that those wetlands that had boundaries were not degraded.

6) In the Central region, where people have strong attachments to the Monarchy, wetlands should be owned by the King (Kabaka) since He is regarded as the Landlord, the sole owner of natural resources, including wetlands and his subjects regarded as the caretakers of the resources. However, generally, over half (51\%) of the respondents stated that wetlands should be owned by local people and local organized groups, if wetland resources must be sustainably utilized and conserved as confirmed by one respondent at S01024.876/ E029056.569/ that said:

'Wetlands are God given, and therefore, they should be owned by members of the local community so that they are able to benefit all the local people living in the area'

For some sections of respondents (33\%) which included those members who had some knowledge about wetland ownership as provided in the 1995 Constitution that 'wetlands are held in trust by the government for the good of all citizens of Uganda' and those members who have never owned land adjacent to the wetlands, or never belonged to any local organized groups, reported that wetlands should be owned by the government. The respondents were of the view that if wetlands are owned by the government, then all the people would be able to access wetland resources with minimum restriction from other stakeholders.

Table 3. Respondents' Awareness and Sources of Information obtained by the Respondents Concerning Wetland Conservation in the Study Areas, Author's questionnaire survey

\begin{tabular}{|c|c|c|c|c|c|}
\hline Awareness & $\begin{array}{l}\text { Number of } \\
\text { responses }\end{array}$ & Percent of cases & Source of information & $\begin{array}{l}\text { Number of } \\
\text { responses }\end{array}$ & Percent of cases \\
\hline \multirow{6}{*}{ Aware } & \multirow{6}{*}{176} & \multirow{6}{*}{44} & Community meetings & 90 & 51 \\
\hline & & & Local radio & 49 & 28 \\
\hline & & & Local Television & 7 & 4 \\
\hline & & & Areas of worship & 5 & 3 \\
\hline & & & News Papers & 4 & 2 \\
\hline & & & Other (Colleagues) & 21 & 12 \\
\hline Not Aware & 224 & 56 & & & \\
\hline Total & 400 & 100 & & 176 & 100 \\
\hline
\end{tabular}

\subsection{Assessment of the performance of existing} wetland management Institutions towards the protection and conservation of wetlands by members of the local community

The Institutions that were included in the study included National Environment Management Authority and the Wetlands Management Department, in regard to implementation of what was stated in the Acts, Statutes, and Policies concerning sustainable wetland resource utilization and conservation in Uganda. The Institutions still uphold and implement the guidelines set in the Land Act (1998) of Uganda concerning land ownership. The Land Act still recognizes four tenure systems: the Customary, the Freehold, the Mailo, and the Leasehold. Each of these tenures has specific and unique goals but there is no specific designated area in the Country where a particular tenure system is implemented. In some cases, like the Central region, land ownership and management is concurrently by Mailo, Freehold and Leasehold. For example, whereas under a Freehold tenure system of ownership, the land holder exercises full powers of ownership of the land and can perform any transaction like selling or disposing of it as a gift. The Leasehold system allows an individual to utilize land for a specified period (49 years or 99 years) for development like building. This leaves members of the local community in a state of confusion as to which tenure could be practiced in order to aim for the conservation of land and wetlands.

The National EnVironment Management Policy (1994) sought amongst other things, to: promote a positive attitudinal change in the way wetland resources were being used by members of the local community by: establishing an effective 
monitoring and evaluation system as well as an Environmental Impact Assessment process and Standards Mechanism; and providing for an effective information management system to facilitate collection, analysis and dissemination of Environmental Information. From the information documented so far in section 4.2, it can be observed that a few respondents (44\%) were aware of the wetland conservation measures while a larger proportion (56\%) of the respondents were not aware of these. In addition, it was realized for example that out of a total of 225 Environmental Impact Assessments conducted for developments, only 34 Environmental Impact Assessments were done on wetlands for the year 2014; and yet a lot of developments were observed as taking place in the wetlands. Such scenarios left the wetlands degraded by members of the local community, confirming that very little was done to implement what was stated in the Policy which aimed at the conservation of wetlands.

The National Environment Statute (1995) for Uganda was enacted aiming for the sustainable management of the environment including wetlands; and to establish an Authority (National Environment Management Authority) as a coordinating, monitoring, and supervisory body of all activities in the field of the environment. The established Authority was to ensure, among other things, the conservation of the environment and sustainable use of natural resources in Uganda, taking into account the rate of population growth and productivity of the available resources; reclaim lost ecosystems where possible and reverse the degradation of natural resources; and establish adequate environmental protection standards and to monitor changes in environmental quality. Whereas although National Environment Management Authority was established as one of the goals of the Policy, the study revealed that it could not effectively carry out its duties related to wetland conservation. Among other things, reclamation of lost ecosystems has to a small extent been realized in a few places, while in other places predominantly occupied by peasants and where the upland soils have become infertile, the increase in the population exhibited by an average of four members, in $68 \%$ of households, continued to drive members of the local community to use the wetlands to seek a livelihood and these ended up being degraded. Environmental Protection at the community level has been unsuccessful due to a lack of manpower to effect its implementation at grass roots level. As already stated, vacancies for the position of Secretary for Production and Environment at the Local Council 1 level have not been filled and also the Sub-county Committees responsible for environmental protection are non - functional. In addition, it was realized that apart from two districts, Wakiso and Kampala, all other districts where the study was conducted, only employed one Natural Resources Officer to overlook natural resource use, including wetlands. This lack of manpower at the Local Council level has been attributed to inadequate funding and culminated in the misuse of natural resources and degradation, of wetlands as stated below by one Natural Resources Officer from the Central region:

'Sometimes, wetlands in this area are degraded during the night or during the week-ends by the financially stable individuals of this community when public offices are closed. These individuals hire many trucks which are used to ferry stones and soil which are dumped into the wetlands, preparing for industrial, and or house construction. By the time it is realized that such degradation has taken place, restoration of such wetlands becomes difficult even if the culprits are evicted. This is because the exercise of scooping out the dumped stones and soil from the wetlands would be very costly to the already financially constrained department'.

Thus, it can be observed that whereas mechanisms for the sustainable utilization and conservation of wetlands by members of the local community are in place, some circumstances including increased population growth; lack of knowledge about indirect functions of wetlands; confusing land tenure systems; and inadequate funding have not encouraged community conservation of wetlands in the study area.

\section{Discussion}

High population growth at an average of 3\% annually, (US Census Bureau, 2006), with an average of four members in $68 \%$ of the households, coupled with infertile soils in upland gardens unable to support the growth of crops for a daily livelihood for members of the local community who are mainly peasants (85\%); of whom the majority $(74 \%)$ never studied beyond primary seven level of education, are some of the reasons responsible for wetland degradation in the study area. As noted by HARTTER \& RYAN (2009), when land is used more intensively, it leads to the establishment of new farms that culminate in a decrease in the sizes of land parcels when the population grows. Other scholars like NTAMBIRWEKI (1998) also affirm that population pressure, coupled with the resulting tendency of people perceiving wetlands as 'free land' has led to the degradation of wetlands in Uganda. Also, according to GOMBYA- 
SSEMBAJJWE \& BANANA (1998), CHAPMAN ET AL. (2001), MACLEAN ET AL. (2003), and HARTTER \& SOUTHWORTH (2009), wetlands in Uganda are declining because they are regarded as the main resource cache and essential for agricultural expansion and for the survival of the majority of the rural population. TIMMER (2004), MWANIKAH (2006), SARUKHAN (2006), TAFARA-GADZIRAYI ET AL. (2006), ACRENAZ ET AL. (2007), and House ET AL. (2008) state that food production for the increasing population in biodiversity rich regions is a driving force behind the loss of biodiversity and ecosystem services especially in marine ecosystems.

The Rural to Urban transformation has also led to the degradation of wetlands in the study area. Wetlands in Uganda are regarded as land most easily available and economically viable for industrial development as reported by NTAMBIRWEKI (1998) and BOS ET AL. (2005). It has also been reported by IUCN (2003) that the increasing rate of urban populations in Uganda created a growing demand for housing and land for settlement that resulted in rapid construction, and industrial and commercial activities that took place in wetlands. Infrastructure developments in urban areas, as reported by SCHWARTZMAN ET AL. (2000), contribute to the destruction of natural resources including wetlands.

Confusion surrounding land ownership among members of the local community also contributed to wetland degradation in the study areas. A report concerning wetland ownership in the Kabale district in south-western Uganda stated that people who own land adjacent to wetlands had a right to prevent other members of the society from harvesting wetland resources close to their land as stated by MACLEAN ET AL. (2003). Other scholars like PIMBERT \& PRETTY (1997) and TIMMER (2004) have reported that degradation of natural resources including wetlands tend to be pronounced when ownership is not clear and local communities have not been granted secure usufruct right over the natural resources. Where very few local community members hold legal titles to land and without secure property rights as reported by PAgDEE ET AL. (2006), Rudel (2006), and LE BEL ET AL. (2011), small land holders show little inclination to participate in natural resource conservation.

Low levels of awareness, where the majority (74\%) of respondents never studied beyond Primary seven level of education, hindered members of the local community to practice the necessary conservation measures to prevent wetlands from being degraded. This is in agreement with BAKEMA \& IYANGO (2001), HARTTER \& RYAN (2009) who stated that wetland management problems in
Uganda are due to insufficient awareness about the functions and benefits that wetlands provide to the local people; and that unprotected wetlands are often viewed as 'unclaimed' and 'unused' areas which provide opportunities to increase landholdings. Relevant education, technical advice and training as reported by GOLDMAN (2003), broadens stakeholders' understanding of conservation; which increases stakeholders' capacities to envision additional means of contributing to the conservation of natural resources. Also, education about the ecological and physical aspects of an ecosystem, as reported by Milton (2000), Mbaiwa (2004), PretTy \& SMITH (2004), BAN ET AL. (2009), and ANDRADE \& RHODES (2012), is paramount for the success of any participatory management approach of natural resources including wetlands.

The presence of illegitimate local council leaders has contributed to wetland degradation in the study areas. In Uganda, Local Council leaders were given power to manage and enforce compliance to the Country's natural resources according to the 1995 Constitution and 1997 Local Government Act as reported by BAZAARA (2002), and HARTTER \& RYAN (2009). Now that local councils seem to be functionally absent, natural resources are left to be misused. In relation to what has been reported, PIMBERT \& PRETTY (1997) posit that natural resource degradation in developing countries originates from the dissolution of local level Institutional arrangements whose purpose was to give rise to sustainable resource use patterns.

An inadequate capacity of the Lead Agencies to implement Policies and Laws at the grass roots level which were aimed at safeguarding wetlands from being degraded has also escalated wetland loss in Uganda. Low numbers of enforcement staff at the grass root level; insufficient funding for wetland conservation programs; could not encourage sustainable utilization and conservation of wetlands in Uganda. Weak law enforcement, as reported by BANANA ET AL. (2001), NKONYA ET AL. (2005), AKELLO (2007), and HARTTER \& RYAN (2009), renders most of the natural resources under the control of Central government, and in some cases open access, vulnerable to degradation. Lack of operating funds as stated by ABRAMS ET AL. (2009) has always been a block in providing effective conservation mechanisms of natural resources in Africa. In Uganda, limited operating budgets and manpower, have always forced the District Environment Officers to concentrate monitoring and enforcement efforts only in more accessible areas, leaving out those resources that are in 
remote areas, hence rendering such resources prone to degradation as reported by GOMBYA-SSEMBAJJWE \& BANANA (1998) and HARTTER \& RYAN (2009).

It can be observed that a plethora of circumstances has led to continued degradation of wetlands in the study area and hence could not encourage the conservation of wetlands by members of the local community. If community conservation of wetlands is to be realized, most, if not all of the above hindrances must be addressed.

\section{Conclusions}

An array of livelihood activities has taken place in the wetlands of Uganda. Such activities include gathering materials for building and crafts; clay and sand mining for molding bricks for building and sale; and fuel wood collection for domestic use amongst others. Agriculture is practiced in the degraded wetlands which have been regarded as 'free and fertile' for crop growing to feed the fast growing population in the study areas. In addition, the funds obtained from the sale of crops grown in the degraded wetlands and also from the products of other activities carried out in the wetlands has improved the livelihoods of the members of the local community through purchase of other household requirements, payment of medical care, school fees, and improvement of household income generating projects. Such incentives obtained from the degraded wetlands continue to encourage members of the local community, who are predominantly peasants who own land that has become infertile, view wetlands as the only solace for daily survival. Such situations culminate in the further degradation of wetlands in Uganda. Until members of the local community are able to appreciate the indirect functions wetlands provide, mainly through increased awareness/public education; streamlined ownership of wetlands; alternative income generating projects introduced at grass roots level; and equipping the Lead Agencies to effectively implement sustainable utilization and conservation measures to members of the local community as stipulated in the Acts, Statutes and Policies that are concerned with wetland conservation; then, $\mathrm{CBC}$ of wetlands in Uganda may never be realized.

\section{References}

Abrams R.W., Anwana E.D., Ormsby A., Dovie D.B.K., Ajagbe A., Abrams A. 2009. Integrating Top-Down with Bottom-Up Conservation Policy in Africa. Cons. Bio., 23 (23): 779-804.

Acrenaz M., Dabek L., O'Neil S. 2007. The Costs of Exclusion: Recognizing a Role for Local Communities in Biodiversity Conservation. PLoS Bio., 11(5): 2443-2448.
Akello C.E. 2007. Environmental Regulation in Uganda. Successes and Challenges. Law, Environ. Dev. J. Uganda.

Andrade G.S.M., Rhodes J.R. 2012. Protected Areas and Local Communities: an Inevitable Partnership toward Successful Conservation Strategies? Ecol. Society, 17(4): 14.

Bakema R.J., Iyango L. 2001. Engaging Local Users in the Management of Wetland Resources: the Case of the National Wetlands Programme, Uganda. IUCN Eastern Africa Regional Office, Nairobi.

Ban N., Hansen G., Jones M., Vincent A. 2009. Systematic marine conservation planning in data-poor regions: socioeconomic data is essential. Marine Pol., 33:794-800.

Banana A.Y., Gombya-Ssembajjwe W., Bahati J. 2001. Explaining Deforestation: The Role of Forest Institutions in Ugandan Forests. A Policy Brief. UFRIC Makerere University, Kampala.

Barrow E., Gicholi H., Infield M. 1997. Comparative Review and Analysis of Community Conservation in East Africa. Working Paper. African Wildlife Foundation. Nairobi-Kenya.

Barrow E., Gicholi H., Infield M. 2000. Rhetoric or Reality? A review of community conservation policy and practice in East Africa. IUCN. East Africa. Nairobi, Kenya.

Bazaara N. 2002. Politics, legal land reform and resource rights in Uganda. Centre for Basic Research, Kampala.

Berkes F. 2007. Community-Based Conservation in a Globalized World. Natural Resources Institute, University of Manitoba, Winnipeg, MB, Canada.

Bos E., Muhweezi A., West K. 2005. From Conversion to Conservation. Fifteen Years of Managing Wetlands for People and the Environment in Uganda. Kampala, Uganda.

Branch K., Hooper D.A., Thompson J., Craghton J.C. 1984. Guide to Social Impact Assessment. Boulder, Westview Press.

Chapman L.J., Balirwa J., Bugenyi F.W.B., Chapman C., Crisman T.L. 2001. Wetlands of East Africa: biodiversity, exploitation, and policy perspectives. [in:] Gopal B., Junk W.J., Davis J.A. (eds.) Biodiversity in Wetlands: Assessment, Function and Cons., vol. 2. Backhuys Publ., Leiden: 101-131.

Daffa J.W., Gamaya K.L., Mashamba C. 2002. Protection of Wildlife and Human Rights on a Balance Sheet: A Case of Killings in the Serengeti National Parks. Dar-es-Salaam: Legal and Human Rights Centre.

Forgie V., Horsley P., Johnston J. 2001. Facilitating Communitybased Conservation Initiatives. Science for Conservation. Report No. 169, Department of Conservation, Wellington, New Zealand.

Ghimire K.B., Pimbert M. P. 1997. Social change and conservation. Environmental politics and impacts of national parks and protected areas. Earthscan and UNRISD, London.

Goldman M. 2003. Partitioned Nature, Privileged Knowledge: Community-based Conservation in Tanzania. Dev. Change., 34(5): 833-862.

Gombya-Ssembajjwe W., Banana A. Y. 1998. Property rights and the sustainability of forests in Uganda. [in:] Presented at International Association for the Study of Common Property, Vancouver, British Columbia, Canada, June 10-14.

Hartter J., Ryan S. J. 2009. Top-down or bottom-up? Decentralization, natural resource management, and usufruct rights in the forests and wetlands in western Uganda. Land Use Pol., 27: 815-826.

Hartter J., Southworth J. 2009. Dwindling resources and fragmentation of landscapes around parks: wetlands and forest fragments around Kibale National Park, Uganda. Landscape Ecol., 24 (5), 643-656.

Hoggart K., Lee L., Davies A. 2002. Researching Human Geography. London, Arnold.

Hough J.L., Sherpa M.N. 1989. Bottom-up vs. basic needs: integrating conservation and development in the Annapurna 
and Michiru Mountain Conservation Areas of Nepal and Malawi. Ambio, 18(8): 431-41.

House A.P.N., MacLeod N.D., Cullen B., Whitbreed A.M., Brown S.D., McIvov J.G.M. 2008. Integrating Production and Natural Resource Management on mixed farms in Eastern Australia: The cost of Conservation in agricultural landscapes. Agr. Ecosystems Environ., 127:153-165.

Hyman D., McKnight J., Higdon F. 2001. Doing Democracy: Conflict and Consensus Strategies for Citizen, Organisation, and Communities. New York, Erudition Press.

IUCN. 2003. Integrating Wetland Economic Values into River Basin Management. Nakivubo Swamp, Uganda.

Le Bel S., Murwira A, Mukamuri B., Czudek R., Taylor R., La Grange M. 2011. Human wildlife conflicts in southern Africa: riding the whirl wind in Mozambique and in Zimbabwe. [in:] López-Pujol J. (ed.). The importance of biological interactions in the study of biodiversity. InTech, Croatia: 283-322.

Lindlof T.R., Taylor C.B. 2011. Qualitative Communication Research Methods. 3 ${ }^{\text {rd }}$ Ed. SAGE Publ., Inc. 2455 Teller Road, Thousand Oaks, California, 91320.

Maclean I., Tinch R., Hassall M., Boar R. 2003. Towards Optimal Use of Tropical Wetlands: an Economic Valuation of Goods Derived from Papyrus Swamps in Southwest Uganda. Environmental Change and Management Working Paper ECM03-10. Centre for Social and Economic Research on the Global Environment, Norwich.

Mbaiwa J.E. 2004. The Success and Sustainability of Communitybased Natural Resource Management in the Okavango Delta, Botswana. South African Geog. J., 86(1): 44-53.

Milton S.J. 2000. Community-Based Conservation: Exploring Positive Feedback between Economic Development and Conservation. SA. J. of Sc., 96.

Ministry of Natural Resources. 1995. The National Environment Management Policy. Kampala, Uganda.

Munthali S.M. 1993. Traditional and Modern Wildlife Conservation in Malawi: the need for an integrated approach. Oryx, 27: 185-187.

Murphree M.W. 1993. Communal Land Wildlife Resources and Rural District Council Revenues. Presented to the CAMPFIRE Association Annual General Meeting, 16 December. Centre for Applied Social Studies. Occasional paper series No. 51/93. Harare, Zimbabwe.

Murphree M.W., Hulme D. (eds.). 2001. African wildlife and livelihoods: the promise and performance of community conservation. London: James Currey.

Mwanikah M.0. 2006. Sustainable us of papyrus cyperus papyrus at Lake Victoria wetlands in Kenya. A case study of Dunga and Kusa swamps. Institute of International Education. National Museums of Kenya.

Ministry of Water and Environment, 2005. Water and Sanitation Sector Performance Report. Ministry of Water and Environment, Kampala. Uganda.

Ministry of Water and Environment. 2009. Water and Sanitation Sector Performance Report. Ministry of Water and Environment, Kampala. Uganda.

National Environment Management Policy. 1994. Ministry of Natural Resources. Kampala. Uganda.

National Policy for the Conservation and Management of Wetland Resources. 1995. Ministry of Water and Environment. Wetlands Management Department. Kampala, Uganda.
National Wetlands Conservation and Management Programme. 1998. Final report on External Review Mission, Royal Netherlands Embassy, Kampala- Uganda.

Nkonya E., Pender J., Kato E., Mugarura S., Muwonge J. 2005. Who Knows, Who Cares? Determinants of Enactment, Awareness and Compliance with Community Natural Resource Management By-laws in Uganda. CAPRi Working Paper, 41. Washington, DC.

Ntambirweki J. 1998. The evolution of policy and legislation of wetlands in Uganda. Technical Consultation on Designing Methodologies to Review Laws and Institutions Relevant to Wetlands. Gland, Switzerland.

Pagdee A., Kim Y., Daugherty P. 2006. What makes Community Forest Management Successful: a meta-study from community forests throughout the World. Society Nat. Res., 19:33-52.

Pimbert M.P., Pretty J.N. 1997. Diversity and Sustainability in Community-based Conservation. Paper for the UNESCOIIPA Regional Workshop on Community-based Conservation, February 9-12, India.

Pretty J., Smith D. 2004. Social capital in biodiversity conservation and management. Conserv. Biol., 18 (3): 631-638.

Rudel T.K. 2006. Shrinking Tropical Forests, Human Agents of Change, and Conservation Policy. Conserv. Biol., 20(6): 1604-1609.

Sarantakos S. 2005. Social Research. Houndmills, Basingstoke, Hampshire RG21 6XS and 175 Fifth Avenue, New York, N.Y.10010 Palgrave MacMillan.

Schwartzmann S., Moreira A., Nepstad D. 2000. Rethinking tropical forest conservation: perils in parks. Conserv. Biol., 14(5):1351-1357.

Sharma U.R. 1990. An overview of park-people interactions in Royal Chitwan National Park, Nepal. Landscape Urban Plan., 19:133-4.

Tafara-Gadzirayi C.E., Mutandwa E., Chihiya J., Chikosha M. 2006. Indeginous Knowledge Systems in Sustainable utilization of wetlands in communal areas of Zimbabwe. Case of Hwedza district. Zimbabwe.

Thatcher P.S. 1984. Peril and opportunity: What it takes to make our choice. [in:] McNeely J. A., Miller K. R. (eds.) National Parks, Conservation and Development: the Role of Protected Areas in Sustaining Society: $12-14$.

The National Environment Statute. 1995. Statute Supplement to the Uganda Gazette. Number 21. Volume LXXXVIII. Printed by UPPC, Entebbe.

Timmer V. 2004. Community-based Conservation and Leadership: Frameworks for Analyzing the Equator Initiative. CID Graduate Student Working Paper No. 2, Cambridge MA: Science, Environment and Development Group, Center for International Development, Harvard University.

Uganda Bureau of Statistics, 2002. Population and Housing Census Report. Uganda Bureau of Statistics. Kampala, Uganda.

Wetlands Management Department. 2013. Wetlands and the Law. Legislation governing the ownership, use and access to wetlands and their resources. Ministry of Water and Environment, Kampala, Uganda. 